\title{
Fylla har ikke skylda
}

Denne legen spør om det er nødvendig med alkohol i behandlingen av spanskesyken (Tidsskr Nor Legeforen 1918; 21: 943-44). Han tror ikke det, tvert imot, han stiller spørsmål ved om det kan være farlig. Nå er vel alle enige om at det rett og slett er slik at av alt som ikke hjelper mot forkjølelse og influensa, er konjakk det beste ...

\section{Er spirituosa nødvendige i influenza («spansk syke»)?}

\author{
Av A. Kløvstad, Røyken.
}

Ovenstaaende spørsmaal har fremstillet sig for mig under den nuværende influenza («spansk syke»)-epidemi mange ganger, tildels fordi enkelte av vore ledende læger har anbefalt bruken av disse midler. Efter min erfaring tør jeg nu besvare spørsmaalet med et avgjort «nei». Jeg har nemlig de forløpne 3 maaneder - juli, august, september - behandlet henholdsvis 204, 59 og 34 (til sammen 297) tilfælder av den spanske syke uten at ordinere en draape av alkoholika. Av mine patienter døde tre. Den ene var en 32 aarig kone, som tidligere hadde havt lungetuberkulose, men tilsynelatende var blit helbredet. Hendes influenza blev komplicert med lungebetændelse og en sterk diarré. Den anden var en 20 aar gammel gut, hos hvem der i tilslutning til influenzaen utviklet sig meningit (tuberkuløs?) Den tredje var en 18 aar gammel gut, som tidligere hadde havt flere pneumonier. Han fik ogsaa nu pneumoni og albuminuri og døde efter et noksaa langt sykeleie. Disse 3 strøk med, og jeg tror ikke, at kognak eller noget andet kunde ha reddet dem. Av de 297 tilfælder var der 11 uttalte pneumonier, 2 sandsynlige pneumonier (med karakteristisk sputum men intet karakteristisk fysikalsk fund) og 6 alvorlige bronkiter.

Mens jeg saaledes i henhold til mine erfaringer føler mig aldeles sikker paa, at alkoholika uten skade kan undværes i influenza, saa er det et andet spørsmål, som jeg ogsaa har stillet, men som jeg ikke føler mig kompetent til at besvare, nemlig: E r a $1 \mathrm{k} \mathrm{o} \mathrm{h} \mathrm{o} 1$ skadelig i influenza? Dette spørsmaal kan jeg ikke svare paa, da jeg ikke har brukt alkohol. Jeg vil henstille til dem, som har brukt alkohol til sine patienter, at komme med sine erfaringer i denne henseende. Naar jeg læser om de mange dødsfald andre steder av denne sygdom - ofte unge kraftige mennesker i sin bedste alder maa jeg spørre mig selv: hvorfor dør disse? Er de blit behandlet med alkohol?

Ja, det var kun disse bemerkniger jeg hadde at gjøre, om De skulde finde dem værdige til at publiceres.

Slemmestad, Røyken, 15de oktober 1918.

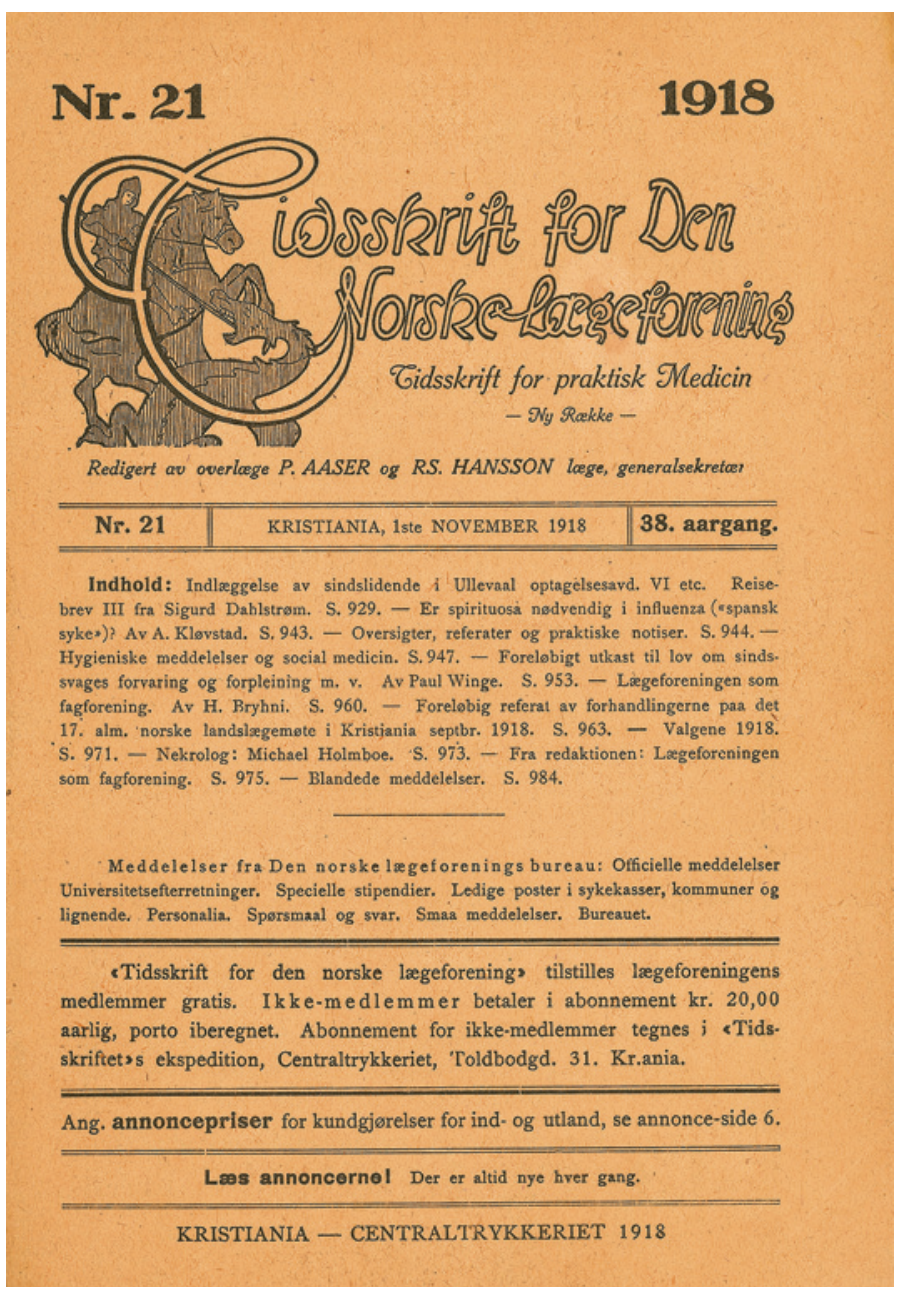

